\title{
Intermission: Interstitial moments in creative and cruel practice
}

\author{
John Di Stefano \\ and Dorita Hannah
}

1 This aligns with Peggy Phelan's contention that theatre is "a kind of mausoleum, a space designed to summon the phantasmatical charge of the immaterial" (1993: 2). The summoning of theatre's phantasmagoria also exposes excess expressed through violence, ecstasy and death - which resists rationalisation and containment.

2 Through a contractual and communal suspension of disbelief, the staged performance witnessed by the gathered collective within the 'house' integrates the here and now with the there and then.

3 Javier Tellez' Intermission was commissioned as part of One Day Sculpture, a series of temporary, place-based public artworks involving New Zealand-based and international artists - each of whom were invited to produce a new work that occurred during a discrete 24 -hour period over the course of one year. Led by the Litmus Research Initiative (Massey University, Wellington) and Claire Doherty (UK-based curator, writer and Director of Situations at the University of the West of England, Bristol), One Day Sculpture was produced in partnership with art institutions and curators across New Zealand and realised in Auckland, Wellington, Taranaki, Christchurch and Dunedin from June 2008 to June 2009.

\section{Sudden death on the pavement}

On September 10, 1985, four near-naked, powder-white bodies were in the process of being gradually lowered from Seattle's Mutual Life Bank Building on the corner of First Avenue and Yessler Way. Suspended by their ankles high above a gathered crowd, these butoh dancers from the company Sankai Juku were beginning "Sholiba" - a slow 30-minute descent to the ground - when one of the ropes broke, sending the body of Yoshiyuki Takada hurtling 80 feet to the pavement, where he died instantly. Dance theorist, Michelle Dent, who witnessed this event, has written that many in the crowd "gasped and clung to the possibility that this was not a human being lying at our feet, but a simulation, some sort of macabre and tricked up theatrical dummy" (Dent 2004: 129). In this moment held between death and its mimesis, Dent maintains, the audience on the street occupied a "liminal space". In The Ritual Process, Victor Turner rendered liminal space as a caesura where time and place are suspended and spectators inhabit a gap "between two thresholds, between two worlds" (Dent 2004: 178): between the everyday and the staged spectacle: between the threat of danger and its inevitable promise. Sankai Juku's director Ushio Amagatsu referred to this interstitial condition when he wrote, three years before the Seattle accident, "Butoh belongs both to life and death. It is a realisation of the distance between a human being and the unknown." (Quoted in Hoffman and Holborn 1987: 121) The liminal experience of theatrical death on the city pavement is both psychic and spatial as it involves that literal gap between a risk of falling and its credible realisation. But what happens within the seemingly safe confines of the purpose-built theatre, where audience expectations are socially and spatially regulated, when theatre's controlled container - the auditorium is unsettled by the incursion of that which it "plays" out? ${ }^{1}$

This paper is organised around two events in which terror literally took to the theatre, shaking our notions of live performance as a carefully controlled event, orchestrated for the reception of a safely distanced and somewhat passive audience. In the architecture of the cinema/theatre's auditorium - a container for the inherently uncontainable performing body (of assembled collective and performer) we explore the eruptive and transformative moment that occurs when the staged event is destabilised by what Lacan refers to as an "irruption of the Real" - the unexpected act that momentarily ruptures the field of symbolically constructed representations with something that exceeds it (1990: 36). This uncanny presencing takes place when the constructed homogeneity of theatrically focused space and time within the theatre's interior is interrupted and broken by an unscripted and unimaginable "exterior" element. ${ }^{2}$ We refer to this interruption as an "intermission" - defined not only as a pause between acts but also as a traumatic interval that involves a momentary spatiotemporal cessation.

The paper's title refers to Intermission (2009): ${ }^{3}$ a work of Venezuelan artist Javier Téllez in which a live lion encounters a live audience in a small-town cinema in rural New Zealand. This piece opens up the interior space of the theatre - a temporal site traditionally negotiating between the staged fictive performance (there and then) and lived reality (here and now). The encounter dangerously blurs the line between the imagined and the real. Disrupting the continuity of narrative and 
assumed spatial practices of both performers and spectators, it recalls Antonin Artaud's demand for a theatre that enacts a more immediate, dangerous and difficult relationship between performance and public. This gains a particular resonance when discussed alongside the 2002 siege of Moscow's Dubrovka Theatre in which a staged performance was violently disrupted by Chechen rebels who took performers and public hostage within the auditorium. Here the interruptive moment causes a discontinuity between the fictive and the real within the more overtly socio-political context of a global media event.

\section{Enter Artaud (screaming)}

Our theory of "intermission" is strongly influenced by the writings of surrealist artist and actor, Antonin Artaud, who called for a Theatre of Cruelty in order to establish a more direct relationship between spectator and spectacle, summed up by André Green as follows:

He aims to provoke in the theatrical event, at any price, a frisson that shakes the spectator out of his passivity, out of the softening seduction that anesthetizes him by way of the pleasant, the picturesque and the decorative. The theater of diversion must give way to a corrosive theater that will gnaw away at the shell that is constricting it and give us back a forgotten aspect of the spectacle. This is the theater of cruelty. (1997: 145)

Artaud, who wished to undo the theatre of rehearsed representation, was determined to mine spatial depths in order to reveal and release an inherent violence as a restorative force. After exhaustive writing around the subject, his address finally took the form of a scream so extreme it filled what Slavoj Žižek names the "hole in reality which designates the ultimate limit where 'the word fails"” (1992: 239). ${ }^{4} \mathrm{Ar}$ taud's Theatre of Cruelty, as both art form and built form, sought to activate spatial volatility in order to confront and combat cruelty. This paradox is reinforced in his manifestoes that reveal an Architecture of Cruelty as a site of recovery, constituted by a body in peril, space in fragments and form without a centre. ${ }^{5}$

THE STAGE - THE AUDITORIUM: We abolish the stage and the auditorium .... so direct communication will be re-established between spectator and the spectacle, between the actor and the spectator, from the fact that the spectator, placed in the middle of the action, is engulfed and physically affected by it. This envelopment results, in part, from the very configuration of the room itself [...]. The spectacle will be extended, by elimination of the stage, to the entire hall of the theatre and will scale up the walls, will physically envelop the spectator and immerse him in a constant bath of light, images, movements, and noises. The public will be seated in the middle of the room, on mobile chairs which will allow them to follow the spectacle which will take place all around them. (1958: 96-7)

Helen Finter points out that what some saw as "the unbearable exhibition of a mental patient" was, for Artaud, "the unprecedented attempt at exploding the boundaries of a theatrical event" (2004: 48). His failed attempts at a "manifestation of the Real" on stage, where he shocked audiences with improvised actions of extreme suffering, highlighted the impossibility of making himself heard in the theatre. In frustration he contended that only bombs could produce the desired effect (2004: 48). Artaud's scream, like a bomb, was an attempt to challenge the Symbolic and tear the fabric of representation through a cruel intrusion on the stage, akin to what Alenka Zupancic describes as 'a 'materialization' of something

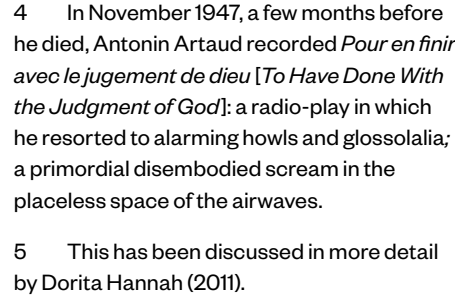
he died, Antonin Artaud recorded Pour en finir avec le jugement de dieu [To Have Done With the Judgment of God]: a radio-play in which he resorted to alarming howls and glossolalia; a primordial disembodied scream in the placeless space of the airwaves.

5 This has been discussed in more detail by Dorita Hannah (2011) 
concealed or repressed ... the intrusion of some "foreign reality"' (1992: 79). This unexpected act, summoning the Real into reality, interrupts the stage fiction with an "alien reality" and disturbs the passivity and clarity of the spectator's vision. ${ }^{6}$

Artaud's scream became a weapon against the Aristotelian mimetic theatre, actively disrupting its focus on the fictive, repetitive and imitative. Its full sonorous force within the traditionally mimetic space of the stage triggered his demand for a theatre that utilised reality rather than representation as the principal medium, allowing architecture to play a more active role in performance itself. However, for Artaud the reality of the "real" included the Real - both interiorised perception and its primordial external dimension - whereby spectacle had to act "not as reflection, but as force" (1976/1984: 4, 297). While his scream was not a literal explosion, it triggered a complex spatial disruption by bringing reality and the Real into fictive staged constructions, performing a complex theatrical architecture of eruption through what Derrida refers to as "Spacing [espacement] ... the archi-manifestation of force, or of life” (Derrida 1997: 46). ${ }^{7}$

The restorative theatre that Artaud proposed offered possibilities to reconcile life with a universe out of control, working with "the underlying menace of a chaos as decisive as it is dangerous” (1958: 51). Contemporary theatre had become decadent because, captivated by illusion and representation, it had broken away "from effects that are immediate and painful - in a word from danger” (1958: 42). Acknowledging and embracing the danger and difficulty inherent in live practice, he wished to create resistant work, transforming the passive spectator into an active creator. A theatrical environment that also physically resists and provokes, challenges the relationships and preconceptions of the body of its audience, which is exposed and acknowledged as a collective of individuals, physiologically affected by performance: disturbed, discomforted and displaced ... dis-eased. Imagine an audience purposefully corralled within the auditorium of a small town awaiting the thrill of danger that comes from extreme and unexpected action.

\section{Javier Téllez' Intermission}

On Sunday 22 March, 2009, the quiet and remote town of Opunake in rural New Zealand that would normally be deserted, found itself teeming with people queuing up to enter Everybody's Theatre, a quaint but rundown 1920s' cinema still in operation today. The local community was mobilised by expectations of seeing something extraordinary that would certainly not repeat itself again in Opunake an event that promised to become the stuff of legend.

6 Lacan referred to the Real as an "impossible" condition exceeding language, which is associated with the preverbal and lost with the entry into language. Artaud, who resisted representation in the theatre and rejected the logic of language, resorted to the scream as a means of fracturing reality and theatrical space (Weiss 2004: 158).

7 Derrida has also referred to spacing (1987: 333-4), as both noun (constructed space) and verb (its active creation), thereby articulating architecture as a performative reality.
Upon entering the interior of the movie theatre, the audience notices that the entire ground floor is vacant except for a small cluster of theatre seats facing the movie screen, which is surrounded by a high, cage-like chain-link fence. The spectators are directed to their seats, both in the stalls and in the balcony area where they have an elevated view of the ground floor. After everyone has been seated, the audience is asked to "stand up for the King" as a vintage film clip of God Save the King, played by the Buckingham Palace Guard band, is projected on the movie screen. After the anthem has finished, and the audience seated, a moving spotlight is illuminated and a side door opens. Oddly gentle utterances of a lion are heard outside - halfway between a roar and a purr - and then "the king" enters the theatre accompanied by his handler, Dalu Mncube.

The place is silent and the spotlight follows the lion as he moves around the "cage" where the audience is seated. Often, the animal comes right up to the fenced area 


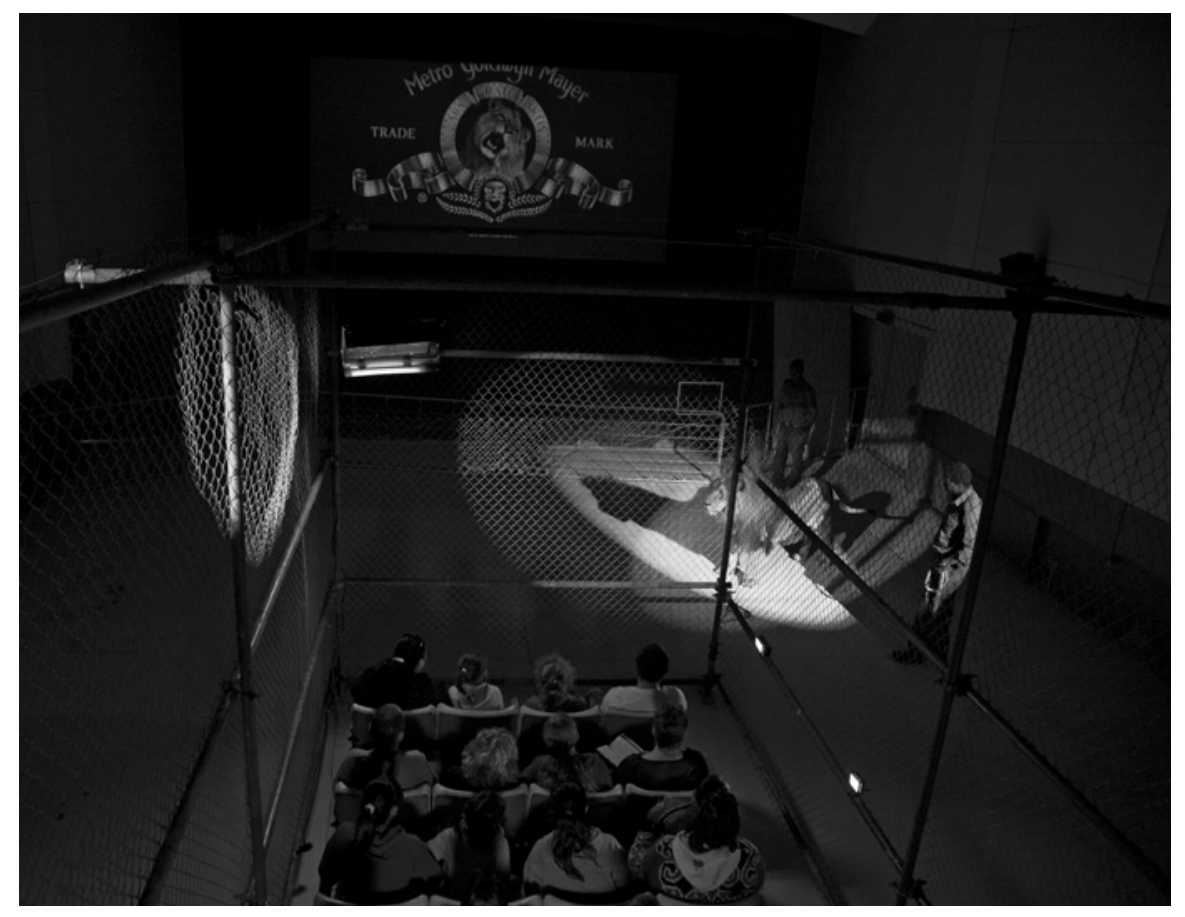

Javier Tellez, Intermission (2009).

Photo: Steve Rowe.

that begins to feel more and more precarious. Seated audience members and lion stare at each other through the chain-link, only inches away. The screen lights up again and the well-known MGM film studio opening credits with roaring lion fills the theatre, interrupting the lion circling the audience. As the handler cajoles the lion around the cage again, he lingers for a while continuing to observe the audience with an intense curiosity. There is an undercurrent of suspense, and after a few more minutes, the lion leaves through the door from which he entered.

Because of the unpredictability of the lion's behaviour, each performance, lasting 10 to 15 minutes, is different. During one sitting, the lion picks up the scent of a small, sleeping baby in the arms of his father seated at the edge of the chain-linked fence. The lion becomes utterly motionless and stares intensely at the child only a few feet away. The audience seated on the ground floor soon becomes aware that they are just as much part of the spectacle, "caged" into a space where the screened performance interfaces with real danger and potential death. It is in the tension between real lion, and preconceived image of "lion" - much of which we have acquired through film - that a powerful undertow of the work emerges.

Fluid moments like this - between distance and proximity, real and imagined, predator and prey - begin to unveil the parameters of Téllez' "spectatorial" event that chips away at the clear distinctions between performance and real life. Téllez mines the schism between the familiarity of the lion's iconographic representation, and the unfamiliarity (even uncanniness) of the real object in our midst. Here the rupture caused by the lion's absolute reality introduces the incomprehensible Real into Everybody's Theatre. Prior expectations that the audience may have had of a lion performing something for them within the realm of entertainment are displaced and reconfigured in favour of something more tangible and unpredictable with elements of danger, and thus somehow more real. Indeed, it is the potential for danger that makes Tellez' work more "real".

Intermission is informed by Tellez' earlier work, El León de Caracas (The Lion of Caracass, 2002), which records the parading of a taxidermic lion, procession-like, 
through one of Caracas' shantytowns by militia-like policemen. Winding its way through the barrio, the lion (also the heraldic symbol of Caracas) is met with fascination and intense interest by the local children who revel in their ability (and permission) to touch and "encounter" the lion as it comes to rest at the bottom of the shantytown. Hands are placed in the lion's open mouth; fingers poke the glass eyes and run through the mane, etc. The (taxidermic) lion here becomes a mediating device by which the local population can interact in a non-violent way with the policemen who are the custodians of the lion, and who would normally have little opportunity to engage with these citizens other than within the confines of aggressive law enforcement. In this work, the lion is transformed into a symbol that embodies the future hope and possibilities for relations - no matter how fleeting they may be - between the disenfranchised and the instruments of power.

Tellez' Intermission (2009) not only disrupts the continuity of narrative and assumed spatial practices but provokes an experience that, like the social interactions facilitated in El Leon de Caracas, is akin to Artaud's radical strategies. The artist presents an opportunity for a localised community to experience something out of the ordinary, and thus opens up the possibility that something "unimaginable" might have the potential of becoming reality. Like the momentary agency the children of the Caracas shantytown found, when they faced their fear of a repressive police force via their encounter with the Lion of Caracas, in Opunake too we might begin to understand the potential agency the encounter with a real lion may illicit. By bringing something "foreign" to Opunake, and eliciting a quasi-traumatic event to provoke a precarious yet rich experience where danger, curiosity and awe converge, Téllez opens up the possibility for its inhabitants to imagine the unimaginable, and in this understated yet radical gesture, offers an opening within the local imaginary of an otherwise isolated community.

An unfortunate but telling postscript to Téllez' work emerged several weeks after Intermission ended. On May 29, Dalu Mncube, the lion-handler in Téllez' artwork, was fatally mauled by a white tiger at the Zion Wildlife Gardens where he worked. Mncube's death became headline news and certainly added to the impact and resonance of Téllez' work for the Opunake residences due to its wide media coverage. As with the fallen butoh performer, the mauled lion-handler fulfills death's promise inherent in the high-risk actions and "circus hyperbole" into which performance company and artist play.

Through what performance theorist Richard Schechner names "dark play" - inherently risky acts that confuse the theatrical frame - subversion, risk and fragility in performance are exposed and thereby realised (1993: 36). ${ }^{8}$ Here we get a glimpse of how the uncanny presencing in Lacan's "irruption of the Real" manifests at the porous borders of theatrical and mass media space and time. Mncube's expected-unexpected death - recalling the expected-unexpected death of the butoh performer - acts as a shock, creating a liminal space of disbelief made only that much more "real" by its mass media dissemination. Artaud's undoing of the conventions of representation is again revisited. For the Opunake residents who witnessed the lion and his handler directly, Mncube's actual death causes something like a delayed reaction in which a repressed vulnerability on the part of the audience is displaced onto (an)other victim. The delayed manifestation of horror

8 Schechner writes: "Dark play occurs when contradictory realities coexist, each seemingly capable of cancelling each other out [...] its end is not integration but disruption, deceit, excess and gratification." (1993:36) and death in the theatre - the intermission - emerges nevertheless, an example of Artaud's art merging with life. 
On October 23, 2002, in the auditorium of Moscow's Dubrovka Theatre, as on the corner of First Avenue and Yessler Way in 1985, the audience could not believe their eyes. The theatre was seized by Chechen rebels who infiltrated it during the musical performance of Nord-Ost, disrupting and transforming the show into a prolonged spectacle of terror that ended with Russia's Spetsnaz soldiers storming the building, having filled it with a narcotic gas that killed over 170 people. In the midst of Act Two, 35 armed guerrillas, with 18 "black widows", burst into the auditorium and onto the stage firing guns and declaring themselves Chechens "at war". At this moment the audience was unsure as to what was theatrical artifice and what was real, who was performer and who was terrorist, who was spectator and who was hostage. ${ }^{9}$ They became part of an event that called into question the parameters of the theatre's auditorium, not dissimilar to Téllez' artistic strategy, only here, the shift had much more overtly political overtones.

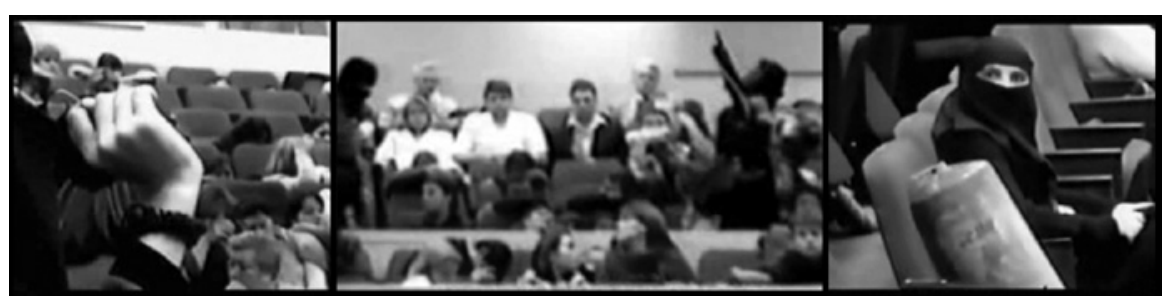

In Moscow, the theatre shifted from site of entertainment to site of warfare. In this moment of radical interruption the very space that the spectators occupied was also called into doubt. No longer an arena for the fleeting acts of entertainment, the 1100-seat auditorium held captive over 800 spectators, performers, theatre workers and terrorists ${ }^{10}$ in a three-day standoff that became a significant historic event ending in tragedy. The interior space of the auditorium, perceived as a house for leisure and amusement or, in this case, a Palace of Culture, was here exposed as an essentially carceral space for all its occupants, emphasising its intrinsic disciplinary nature. The violent event revealed the inherent violence of an architecture ironically designed to control a captive audience.

As a moment of crisis, the Dubrovka Theatre siege exposed the gap between architectural and theatrical realities, unsettling the highly regulated interior designed for the simultaneous and seamless apprehension of art form and built form. Akin to Foucault's "events of thought", such incidents summon something new through the unprepared - unforeseeable, singular, unique and transformative (1972: 215237). Transcending the notion of a logical sequence of actions, they are isolated in what Bernard Tschumi identifies as "the moment of erosion, collapse, questioning, or problematization of the very assumption of the setting within which a drama may take place - occasioning the chance or possibility of another, different setting" (1998: 256). Likewise, the spatial ideas in Artaud's Theatre of Cruelty challenge the conventions of the auditorium and suggest an alternative approach to the disciplinary nature of the archetypal modernist theatre that was besieged in October 2002.

\section{Cruel machine}

As a cruel and impossible mechanism, Artaud's theatre was to be "rebuilt" upon "extreme action, pushed beyond all limits" (Tschumi 1998: 85). Its true and only value was to be found in an "excruciating, magical relation to reality and danger" (89).
Video stills from footage taken by the Chechen rebels during the siege of the Dubrovka Theatre (Moscow: October 2002).
9 For several long seconds the audience assumed the gunmen in ski masks were part of the show. A woman in the audience, who was interviewed on the television documentary (America Undercover - Terror in Moscow, dir. Dan Reed, HBO, 2003), recalls thinking "what a clever theatrical concept".

10 The rebels themselves had become captive in the space, unable to escape once they had entered (many as mem-bers of the audience) and taken it over. 
11 Dolnik and Pilch argue that, in staging a successful nationalistic musical, the theatre was also a place that guaranteed middle to upper class hostages, reinforcing the perception that any citizen can become a target (2003:604)

12 Derrida writes that this is "the profound essence of Artaud's project" (1997: 54).
This Theatre of Cruelty is not one of bloodshed or martyrdom but a cruel apparatus built to combat cruelty, through what Derrida refers to as "the irruptive force fissuring the space of the stage" (1997: 53). And within this opening, the Real, as a traumatic surplus, makes its unbearable presence felt. The invasion of the Dubrovka Theatre, which storms the prescribed limits of a house of entertainment, presents a moment when theatrical and lived realities coincide to reveal the ultimate intrusion - that of death. The stage becomes what Alenka Zupančič calls "a perfect place to die", by taking advantage of "the public setting par excellence, where everything that is said is intended for the audience" (1992: 81). The realm of this particular stage then expands through international media coverage, into a phantasmatic global platform upon which a spectacle of politics is played out.

Adam Dolnik and Richard Pilch call the Dubrovka Theatre hostage crisis an "expressive act" which, like a theatrical production, was planned, rehearsed and enacted. But unlike the conventions of the conventional theatrical "show", any pre-arranged scripting of action in this case was always subject to the unpredictabilities of re-action, despite any number of possible scenarios that may have been taken into account and practiced. Certainly, the selection of this site by the rebels was highly strategic, not only for its centrality and proximity to the Kremlin, but because it guaranteed a large collection of people within a space ideal for "barricade hostage-taking" (Dolnik and Pilch 2003: 577-611). ${ }^{11}$ As a well-planned and rehearsed event it revealed the overt theatricality inherent in such terrorist events, evident in the affective timing, combat uniforms and conspicuous incorporation of weaponry. This is reinforced by the powerful presence of the "black widows" as spectral forms of terror-in-mourning with their veils and bomb-belts. The rebels exploited the familiar interior of the proscenium theatre to dramatically present body and building as explosive and deadly weapons. They wired the clearly marked exits with charges, planted two conspicuous bombs on central seats within the auditorium, and placed the armed bodies of the "black widows" in tactical positions. Observation occurred from points throughout the auditorium and was aided by the self-surveying quality of the space itself. The hermetically-sealed interior space of the auditorium, and its immediate environs, then became a container for the lethal narcotic gas that drugged and eventually killed many of its inhabitants, allowing the armed forces to raid the theatre and execute the rebels who detonated neither bodies nor building.

The Spetsnaz' deadly raid inside the theatre concluded the siege. It was enacted because the authorities were faced with enemies who were not only prepared to sacrifice themselves and others for their cause but "staged their operation with the ultimate goal of their own dramatic demise" (Dolnik and Pilch 2003: 604). Zupančič explains how suicide, as a "borderline act", is "something completely different from 'doing' or 'action'. It incorporates some radical no! to the universe which surrounds it and involves an irreducible moment of risk" (1992: 93). She points out that Lacan's model of the acte came from the act of suicide: every real act is a "suicide of the subject" allowing the subject to be born again as a new subject. This notion is aligned with Peggy Phelan's ontological unrepeatability of performance (1993: 146) and Artaud's desire to erase repetition, which "separates force, presence, and life from themselves" (Derrida 1997: 54). ${ }^{12}$ As a political act, the Dubrovka Theatre siege was cruel in the most obvious sense of the word, rendering the dis-eased spectators no longer passive witnesses, but, as bodies-in-peril, unwilling participants implicated in the force of the event. Dislocated, they are made brutally aware of their disciplinary location. 
Both the Dubrovka Theatre siege and Javier Téllez' Intermission are contemporary examples that highlight the politics of theatre as space and action. As potentially or actually irruptive and violent stagings, both events illustrate how a truly radical political gesture, defined in its broadest terms, might find its place in the interior architectural space of the theatre today. If we are to understand this new paradigm as a break, interruption or suspension, then we must ask ourselves what it disrupts. This new type of theatre/space sets itself up as a counter-point to the homogenising forces of today's mass media, as a place of potential agency. Creating unforseen breaks in the repetition of performance and bringing something "foreign" into representational space, our macabre fascination with violent and disastrous events is revealed, exposing what Slavoj Žižek names "a Thing in a Lacanian sense: the material leftover, the materialization of the terrifying, impossible jouissance, a kind of petrified forest of enjoyment" (1989: 27). Whether or not we are prepared to admit that the pleasure and anxiety of irruptive acts link terror with desire, such events perform a strategic rupture - an intermission - which reconfigures the audience's expectations, opening up the possibility for them to imagine the "unreal" as very real indeed.

\section{References}

Artaud, A. (1958). Theatre and Its Double. New York: Grove Press.

Artaud, A. (1976/1984) Oeuvres Completes, Vol 1 (Part 1): 1946. Paris: Gallimard.

Dent, M. (2004). The Fallen Body: Butoh and the Crisis of Meaning in Sankai Juku's 'Jomon Sho.' Falling: Women \& Performance, 14(1/27), 173-200.

Derrida, J. (1987). Point de Folie: Maintenant l'Architecture. In N. Leach (Ed.) Rethinking Architecture: A Reader in Cultural Theory, 324-36. (Originally published in Bernard Tschumi (1986) La Case Vide: La Villette. London: Architectural Association).

Derrida, J. (1997). The Theatre of Cruelty and the Closure of Representation. In T. Murray (Ed.), Mimesis, Masochism and Mime: The Politics of Theatricality in Contemporary French Thought (40-62). Ann Arbor (Mi.): University of Michigan Press.

Dolnik, A. and Pilch, R. (2003). The Moscow Theater Hostage Crisis: the Perpetrators, their Tactics and the Russian Response. International Negotiation, 8(3), 577-611.

Finter, H. (2004). Antonin Artaud and the Impossible Theatre: the legacy of the theatre of cruelty. In E. Scheer (Ed.), Antonin Artaud: A Critical Reader (47-58). London: Routledge Press.

Foucault, M. (1972). Archaeology of Knowledge and Discourse on Language (A.M. Sheridan, Trans.). New York: Pantheon Books.

Green, A. (1997). The Psycho-analytic Reading of Tragedy. In T. Murray (Ed.), Mimesis, Masochism and Mime: the Politics of Theatricality in Contemporary French Thought (136-162). Ann Arbor (Mi.): University of Michigan Press.

Hannah, D. (2011) Towards an Architecture of Cruelty: Mining the Spatial of Antonin Artaud. In B. Kenzari (Ed.), Architecture and Violence (93-122). Barcelona: Actar Press.

Hoffman, E. and Holborn, M. (1987). Butoh: Dance of the Dark Soul. New York: Aperture.

Lacan, J. (1990). Television. (D. Hollier, R. Krauss, and A. Michelson, Trans.). New York: W.W. Norton and Co.

Phelan, P. (1993). Unmarked: The Politics of Performance. London: Routledge.

Reed, D. (2003), Terror in Moscow. HBO Documentary Film, "America Undercover".

Schechner, R. (1993). The Future of Ritual: Writings on Culture and Performance. London: Routledge Press.

Tschumi, B. (1998). Architecture and Disjunction. Cambridge (Mass.): MIT Press.

Weiss, A.S. (2004). K. In E. Scheer (Ed.), Antonin Artaud: A Critical Reader (151-158). London:

Routledge Press.

Žižek, S. (1989). The Sublime Object of Ideology. New York: Verso.

Žižek, S. (1992). Everything You Always Wanted to Know About Lacan (But Were Afraid to Ask Hitchcock). London: Verso.

Zupančič, A. (1992). A Perfect Place to Die: Theatre in Hitchcock's Films. In S. Žižek (Ed.)

Everything You Always Wanted to Know About Lacan (But Were Afraid to Ask Hitchcock) (73-105).

London: Verso. 